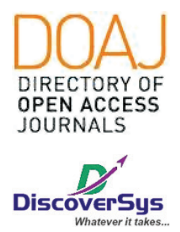

Published by DiscoverSys

\title{
Prevalensi dan hubungan faktor terkait tajam penglihatan pada masyarakat Desa Ngis, Karangasem, Bali tahun 2017
}

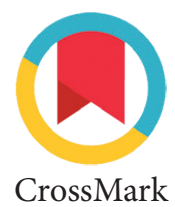

\author{
Haikal Hamas Putra Iqra, ${ }^{1 *}$ Kadek Tresna Yuwana, ${ }^{1}$ \\ Agung Bagus Sista Satyarsa, ${ }^{1}$ Ni Made Ari Suryathi ${ }^{2}$
}

\section{ABSTRACT}

Background: Visual impairment is affected by multiple factors which consists of internal factor and environmental factor especially near work activity and outdoor activity. The role of its factor depends on geographical situation, economical condition and local culture. Aim:This study aims to determine the prevalence of visual acuity reduction and associated factors towards visual acuity of local civilians in Ngis village, Manggis sub-district, Karangasem district, Bali province in 2017.

Method: This study was a cross-sectional descriptive study with a sample of 63 people aged 12-70 years old ( 27 male; 38 female) in Ngis village. The data was obtained through a 6 meter Snellen chart examination and an interview with a questionnaire guide.
Results: The results showed a sharp reduction in vision of the local civilians was 37 people (58.7\%) which varying from mild impairment untill NLP. A significant relationship $(p<0,05)$ between outdoor activity toward reduction of visual acuity (PR=3.008 [95\% Cl: 1,039-8,714]). And another factor such as watching television, usage of smartphone and reading in the room ( $P R=0,659$ [IK 95\%: 0,221-1,962]; $P R=0,579$ [IK 95\%:0,464-0,722]; PR=0,5 [IK 95\%:0,092-2,706]) showed inconsistent relationship.

Conclusion: There are some local civilians in Ngis Village that experienced undiagnosed sharp reduction in visual acuity which affected by multiple factorial.
'Program Studi Pendidikan Dokter, Fakultas Kedokteran, Universitas Udayana, Bali

${ }^{2}$ Departemen IImu Kesehatan Mata, Fakultas Kedokteran, Universitas Udayana, Rumah Sakit Umum Pusat Sanglah, Denpasar Bali

${ }^{*}$ Correspondence to:

Haikal Hamas Putra Iqra, Program Studi Pendidikan Dokter, Fakultas Kedokteran, Universitas Udayana, Bali

hamashaika@@gmail.com

Diterima: 03-09-2019

Disetujui: 10-11-2019

Diterbitkan: 01-08-2020

Keywords: visual acuity, near work activity, outdoor activity.

Cite This Article: Iqra, H.H.P., Yuwana, K.T., Satyarsa, A.B.S., Suryathi, N.M.A. 2020. Prevalensi dan hubungan faktor terkait tajam penglihatan pada masyarakat Desa Ngis, Karangasem, Bali tahun 2017. Intisari Sains Medis 11(2): 470-475. D0l: 10.15562/ism.v11i2.604

\section{ABSTRAK}

Latar Belakang: Banyak faktor yang mempengaruhi dari gangguan penglihatan yang berhubungan dengan tajam penglihatan salah satunya aktivitas jarak dekat dan aktivitas di luar ruangan. Hubungan dari faktor-faktor tersebut bervariasi bergantung pada kondisi geografis, ekonomi dan budaya dari masyarakat setempat.

Tujuan: untuk mengetahui prevalensi penurunan tajam penglihatan dan hubungan faktor terkait terhadap tajam penglihatan pada masyarakat di desa Ngis, kecamatan Manggis, kabupaten Karangasem, provinsi Bali tahun 2017.

Metode: Penelitian ini merupakan studi deskriptif cross-sectional dengan sampel masyarakat umur 12-70 tahun desa Ngis yang berjumlah 63 orang (27 laki-laki; 38 perempuan). Data didapatkan melalui pemeriksaan Snellen chart 6 meter serta wawancara dengan panduan kuisioner.
Hasil: prevalensi penurunan tajam penglihatan penduduk desa Ngis adalah 37 orang $(58,7 \%)$ dengan penurunan tajam penglihatan yang bervarisi dari penurunan ringan hingga NLP. Dari beberapa faktor terkait yang diteliti diperoleh hasil yang signifikan $(p<0,05)$ pada faktor bekerja di luar ruangan ( $P R=3.008$ [IK 95\%: 1,039$8,714]$ ). Beberapa faktor lainnya seperti kebiasaan menonton televisi ( $P R=0,659$ [IK 95\%: 0,221-1,962); penggunaan smartphone ( $P R=0,579$ [IK 95\%:0,464-0,722); membaca dalam ruangan ( $P R=0,5$ [IK 95\%:0,092-2,706) dan aktivitas di luar ruangan tidak menunjukkan korelasi yang signifikan.

Kesimpulan: Terjadi penurunan tajam penglihatan pada penduduk Desa Ngis yang tidak diketahui sebelumnya, hal ini disebabkan oleh berbagai faktor dalam hal ini faktor lingkungan.

Kata kunci: tajam penglihatan, aktivitas jarak dekat, aktivitas luar ruangan

Cite Pasal Ini: Iqra, H.H.P., Yuwana, K.T., Satyarsa, A.B.S., Suryathi, N.M.A. 2020. Prevalensi dan hubungan faktor terkait tajam penglihatan pada masyarakat Desa Ngis, Karangasem, Bali tahun 2017. Intisari Sains Medis 11(2): 470-475. D0I: 10.15562/ism.v11i2.604

\section{PENDAHULUAN}

Gangguan penglihatan merupakan salah satu faktor yang dapat menurunkan kualitas hidup seseorang dan mengganggu aktivitas sehari-hari. World Health Organization (WHO) memperkirakan bahwa terdapat sekitar 1,3 miliar populasi dunia yang mengalami gangguan penglihatan. Dengan sekitar 217 juta populasi mengalami gangguan penglihatan sedang hingga berat. ${ }^{1}$ Berdasarkan 
studi yang dilakukan oleh Bourne dkk menunjukkan bahwa gangguan refraksi merupakan salah satu penyebab utama terjadinya gangguan penglihatan dan penyebab terbesar kedua dari kebutaan. Dari $53 \%$ populasi total yang mengalami gangguan penglihatan diantaranya disebabkan oleh gangguan refraksi dan sekitar 21\% lainnya mengalami kebutaan. $^{2}$

Secara global gangguan penglihatan menyebabkan penurunan produktivitas masyarakat dan kerugian sebuah negara setiap tahunnya. Hal ini dikarenakan gangguan penglihatan dapat menyebabkan penurunan kualitas hidup manusia, seperti menurunnya kemampuan akademik, meningkatnya dependensi hingga meningkatnya bebas psikologi seseorang. ${ }^{3}$ Sehingga intervensi kuratif dan preventif merupakan salah satu langkah terbaik dalam upaya mengatasi gangguan penglihatan yang disebabkan oleh gangguan refraksi tidak terkoreksi.

WHO bersama dengan International Agency for the Prevention of Blindness (IAPB) telah meluncurkan program Global Initiative Vision 2020:The Right to Sight pada tahun 1999, dimana memfokuskan intervensi dan prevensi mata pada kausa kebutaan tertinggi. Dalam hal ini termasuk gangguan refraksi yang tidak terkoreksi dengan baik, meskipun sebagian gangguan refraksi disebabkan oleh glaucoma dan diabetic retinopati. ${ }^{4,5}$

Gangguan refraksi ini dapat terjadi pada semua kelompok usia, terutama pada populasi kelompok usia di atas 40 tahun. ${ }^{6}$ Beberapa studi menunjukkan bahwa gangguan refraksi ini terus mengalami peningkatan, hal ini dikarenakan terjadi perubahan gaya hidup dan aktivitas masyarakatnya yang banyak melakukan aktivitas jarak dekat terutama masyarakat yang berdomisili di daerah perkotaan. ${ }^{7,8}$ Berdasarkan data WHO menunjukkan bahwa $80 \%$ dari gangguan penglihatan dapat dicegah. Seperti perubahan gaya hidup saat ini dimana seseorang menghabiskan banyak waktu untuk membaca, menggunakan komputer atau smartphone dan lebih banyak melakukan aktivitas aktivitas jarak dekat lainnya. ${ }^{8}$ Dibanding dengan aktivitas luar ruangan yang cenderung menurunkan risiko penurunan tajam penglihatan seseorang hingga dua kali lipat. ${ }^{9}$

Hingga saat ini masih jarang ditemukannya laporan terkait dengan prevalensi tajam penglihatan di Indonesia, terutama pada daerah-daerah pedesaaan yang dimana terdapat perbedaan gaya hidup dan aktifitas sehari-hari. Walaupun memang faktor genetik juga mempengaruhi dari tajam penglihatan seseorang, terutama pada pertumbuhan bola mata. Tetapi dalam hubungannya dengan komponen refraksi, lingkungan lebih mengambil andil dalam terjadinya penurunan tajam penglihatan. ${ }^{10}$ Oleh karena itu, penulis berinisiatif untuk melihat hubungan antara aktivitas jarak dekat dan luar ruangan terhadap terjadinya penurunan tajam penglihatan di daerah pedesaan. Dimana penelitian ini dilakukan di Desa Ngis, Karangasem, Bali, Indonesia.

\section{METODE}

Populasi target dari penelitian ini adalah masyarakat Desa Ngis, Kecamatan Manggis, Kabupaten Karangasem. Populasi terjangkau dari penelitian ini adalah seluruh masyarakat Desa Ngis yang hadir di balai banjar berjumlah 63 orang. Populasi terjangkau terpilih dalam jangka waktu Juli 2017. Proses pengambilan sampel dilakukan secara tidak acak (nonprobability sampling) dengan teknik total sampling. Kriteria inklusi pada penelitian ini merupakan masyarakat Desa Ngis yang hadir, bersedia mengikuti peneltian, mengisi kuesioner dan melakukan pemeriksaan tajam penglihatan. Dan kriteria ekslusi pada penelitian ini merupakan masyarakat Desa Ngis yang tidak hadir saar melakukan penelitian dan sedang menderita penyakit mata yang mempengaruhi tajam penglihatan.

Variabel bebas yang digunakan adalah lama aktivitas di luar ruangan, kebiasaan menggunakan computer/smartphone, keluarga yang menggunakan kacamata, kebiasaan menggunakan televisi, dan kebiasaan membaca dalam jarak dekat dan variabel tergantung menggunakan tajam penglihatan. Variabel bebas diukur dengan instrumen penelitian berupa alat dan bahan yang digunakan dalam penelitian yaitu Snellen chart untuk mengukur tajam penglihatan, plain occluder, pinhole occluder, senter, dokumentasi pasien dan daftar pertanyaan berupa kuesioner yang berisi poin-poin perilaku yang berpotensi menjadi faktor resiko pada penurunan tajam penglihatan anak. Langkah pertama adalah menempatkan chart pada tempat yang terang dan subjek pada tempat yang teduh dengan cahaya yang cukup untuk menerangi wajah subjek pada saat tes dilakukan, Posisikan subjek, baik dalam keadaan berdiri maupun duduk, pada jarak 6 meter dari chart. Selanjutnya melakukan pemeriksaan pada subjek dan memberikan kuisioner mengenai faktor risiko gangguan tajam penglihatan. Data diri pada kuisioner disesuaikan dengan subjek yang hadir. Jumlah kuisioner yang didapatkan sebanyak 63 buah.

Pengumpulan data dilakukan dengan cara pemeriksaan langsung tajam penglihatan mata tajam penglihatan dengan Snellen chart dan dari pengisian kuesioner oleh subjek penelitian. Teknik analisis data yang akan dilakukan dengan menggunakna software SPSS. Adapun data yang dianalisis menggunakan teknik analitik dengan chi-square yaitu dengan menghubungkan prevalensi penurunan tajam penglihatan dengan faktor terkait. 


\section{HASIL}

Berdasarkan penelitian yang telah dilakukan (Tabel 1), terdapat 63 subjek yang berpartisipasi dalam penelitian ini dengan jumlah laki - laki sebanyak 27 orang dan perempuan sebanyak 38 orang dengan 30 orang $(37,5 \%)$ mengalami penurunan tajam penglihatan. Median usia responden adalah 63 tahun (rentang usia 6-70 tahun). Menurut kriteria International Classification of Diseases (ICD) 11 tahun 2018, pada mata kanan subjek yang memiliki tajam penglihatan normal sebanyak 26 orang, 8 orang mengalami penurunan ringan, sebanyak 22 orang mengalami penurunan sedang, sebanyak 3 orang mengalami penurunan berat, dan 3 orang mengalami near blindness serta tidak ada orang yang mengalami no light perception (NLP).

Hasil penelitian ini juga menunjukkan bahwa lebih dari $60 \%$ besar penduduk Desa Ngis yang menjadi responden sering beraktivitas di luar rumah, baik itu untuk bekerja ataupun untuk melakukan aktivitas lainnya. Dan ditemukan pula bahwa penduduk yang bekerja dan beraktivitas lebih dari 2 jam di ruang terbuka memiliki risiko 2,454 kali dan 3,008 kali lebih tinggi mengalami penurunan tajam penglihatan dibanding dengan orang yang bekerja di ruang terbuka kurang dari 2 jam $\{(\mathrm{PR}=0,099$ [IK 95\%: 0,835-7,209]);PR=0,039 [IK 95\%: 1,039-8,714])\}.
Sekitar 30\% penduduk Desa Ngis yang menjadi responden penelitian beraktivitas di dalam rumah. Dan ditemukan pula bahwa responden yang beraktivitas di dalam rumah cenderung memiliki risiko lebih rendah mengalami penurunan tajam penglihatan. Salah satunya aktivitas membaca buku di dalam rumah dan menonton TV memiliki risiko lebih rendah untuk mengalami penurunan tajam penglihatan $\{(\mathrm{PR}=0,699$ [IK 95\%:0,0922,706);(PR=0,452 [IK 95\%: 0,221-1,962])\}. Selain itu juga aktivitas penggunaan smartphone di Desa Ngis kurang dari $10 \%$ dari total responden yang diperoleh. Dan hasil analsis menunjukkan bahwa penduduk yang menggunakan smartphone lebih dari 2 jam memiliki risiko 0,5 kali lebih rendah mengalami penurunan tajam penglihatan dibanding dengan penduduk yang tidak menggunakan smartphone.

\section{DISKUSI}

Gangguan penglihatan yang disebabkan oleh gangguan refraksi tidak terkoreksi atau tidak terkoreksi dengan baik merupakan salah satu masalah utama pada semua kelompok usia di berbagai daerah di Indonesia. Permasalahan mata di Bali masih menjadi perhatian pemerintah baik dalam upaya preventif ataupun kuratif. Saat ini pemerintahan Indonesia telah meluncurkan meluncurkan peta

Tabel 1 Karakteristik data responden

\begin{tabular}{|c|c|c|c|c|c|}
\hline & \multicolumn{2}{|c|}{ Tajam Penglihatan } & \multirow[b]{2}{*}{$p$} & \multirow[b]{2}{*}{ PR } & \multirow[b]{2}{*}{$\mathrm{Cl} 95 \%$} \\
\hline & $\begin{array}{c}\text { Normal } \\
\text { n (\%) }\end{array}$ & $\begin{array}{l}\text { Menurun } \\
\text { n (\%) }\end{array}$ & & & \\
\hline \multicolumn{6}{|c|}{ Kebiasaan Menonton Televisi } \\
\hline$<2$ jam & $24(58,5)$ & $17(41,5)$ & 0,452 & 0,659 & $0,221-1,962$ \\
\hline$>2$ jam & $15(68,2)$ & $7(31,8)$ & & & \\
\hline \multicolumn{6}{|c|}{ Memakai smartphone } \\
\hline$<2$ jam & $33(57,9)$ & $24(42,1)$ & 0,043 & 0,579 & $0,464-0,722$ \\
\hline$>2$ jam & $6(100)$ & $0(0)$ & & & \\
\hline \multicolumn{6}{|c|}{$\begin{array}{l}\text { Membaca buku di dalam } \\
\text { ruangan }\end{array}$} \\
\hline$<2$ jam & $33(60)$ & $22(40)$ & 0,699 & 0,5 & $0,092-2,706$ \\
\hline$>2$ jam & $6(75)$ & $2(25)$ & & & \\
\hline \multicolumn{6}{|c|}{ Bekerja di ruang terbuka } \\
\hline$>2$ jam & $28(71,8)$ & $11(28,2)$ & $0,039^{*}$ & 3,008 & $1,039-8,714$ \\
\hline$<2$ jam & $11(45,8)$ & $13(54,2)$ & & & \\
\hline \multicolumn{6}{|c|}{ Aktivitas diluar ruangan } \\
\hline$>2$ jam & $29(69)$ & $13(31)$ & 0,099 & 2,454 & $0,835-7,209$ \\
\hline$<2$ jam & $10(47,6)$ & $11(52,4)$ & & & \\
\hline
\end{tabular}

CI, confidence of interval; PR, prevalence ratio; $\mathrm{p}$, probability 


\begin{tabular}{|c|c|c|}
\hline \multirow[b]{2}{*}{ Karakteristik } & \multicolumn{2}{|c|}{ Visual Acuity $(n=63)$} \\
\hline & $\mathbf{N}$ & $\%$ \\
\hline Usia (Median) & $63(6-70)$ & 100 \\
\hline$-0-20$ & 5 & 7,9 \\
\hline$-21-40$ & 9 & 14,3 \\
\hline$-41-60$ & 31 & 49,2 \\
\hline$->60$ & 18 & 28,6 \\
\hline \multicolumn{3}{|c|}{ Jenis Kelamin, n (\%) } \\
\hline Laki-laki & 27 & 42,86 \\
\hline Perempuan & 38 & 57,14 \\
\hline
\end{tabular}

Status Tajam Penglihatan, n(\%)

Status Penglihatan menurut criteria International Classification of Diseases 11 tahun 2018

$\begin{array}{lcr}\text { - Normal } & 26 & 41,3 \\ \text { - Tidak Normal } & 37 & 58,7 \\ \text { a Penurunan ringan } & 8 & 12,7 \\ \text { b Penurunan sedang } & 22 & 34,9 \\ \text { c.Penurunan berat } & 4 & 6,3 \\ \text { d. Near blindness } & 3 & 4,8\end{array}$

e. NLP

Status Penglihatan mata kanan, n (\%)

Status Penglihatan menurut criteria International Classification of Diseases 11 tahun 2018

$\begin{array}{lcc}\text { - Normal } & 35 & 55,6 \\ \text { - Tidak Normal } & 28 & 44,4 \\ \text { a Penurunan ringan } & 5 & 7,9 \\ \text { b Penurunan sedang } & 16 & 25,4 \\ \text { c.Penurunan berat } & 4 & 6,3 \\ \text { d. Near blindness } & 3 & 4,8 \\ \text { e. NLP } & 3\end{array}$

Status Penglihatan mata kiri, $\mathbf{n}(\%)$

Status Penglihatan menurut criteria International Classification of Diseases 11 tahun 2018

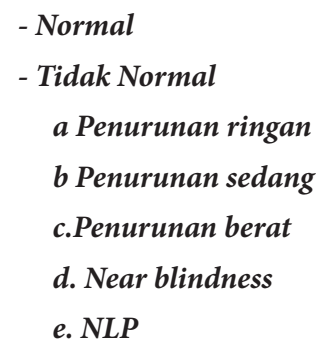

$\begin{array}{cc}30 & 47,6 \\ 33 & 52,4 \\ 6 & 9,5 \\ 19 & 30,2 \\ 5 & 7,9 \\ 2 & 3,2 \\ 1 & 1,6\end{array}$

NLP, no light perception

jalan atau road map penanggulangan gangguan penglihatan 2017-2030 yang bertujuan meningkatkan penanggulangan kebutaan dan gangguan penglihatan. Dimana salah satu impelementasinya adalah dengan menjamin terkoreksinya gangguan penglihatan. ${ }^{11}$

Berdasarkan hasil penelitian yang telah dilakukan ditemukan bahwa penduduk Desa Ngis yang melakukan aktivitas di luar ruangan lebih dari
2 jam dalam satu hari terbilang cukup banyak atau sekitar $65 \%$ dan penduduk yang bekerja di luar ruangan juga terbilang cukup banyak yaitu mencapai lebih dari $60 \%$ dari total responden yang diperoleh. Hal ini sesuai dengan data statistik yang diperoleh bahwa sebagian besar penduduk Desa Ngis bercocok tanam di area perkebunan sekitar Desa. ${ }^{12}$ Penduduk yang banyak melakukan aktivitas di luar ruangan dalam hal ini aktivitas 
bekerja (PR=0,099 [IK 95\%:0,835-7,209]) dan aktivitas luar ruangan lainnya $(\mathrm{PR}=0,039$ [IK 95\%:1,039-8,714]) memiliki risiko mengalami penurunan tajam penglihatan lebih tinggi dibanding penduduk yang melakukan aktivitas luar ruangan kurang dari 2 jam.

Hasil dari penelitian ini berbanding terbalik dengan penelitian sebelumnya yang menunjukkan bahwa aktivitas luar ruangan sebagai faktor protektif cenderung menurunkan tajam penglihatan dibanding dengan aktivitas jarak dekat. ${ }^{13}$ Aktivitas luar ruangan memiliki faktor protektif rendah pada gangguan penglihatan ringan dan tidak menunjukkan hubungan pada gangguan penglihatan berat. Hal ini dikarenakan mayoritas penduduk Desa Ngis bercocok tanam di perkebunan, sehingga terpapar matahari dengan intensitas tinggi dalam kurun waktu yang lama. ${ }^{12}$ Intensitas paparan matahari tinggi ini menyebabkan terjadinya gangguan penglihatan yang menyebabkan penurunan tajam penglihatan semakin tinggi. ${ }^{14}$ Studi lain menunjukkan bahwa responden yang terpapar sinar matahari lebih dari 5,6 jam cenderung mengalami gangguan refraksi lebih buruk dibanding dengan responden yang tidak. ${ }^{15}$

Dalam penelitian ini juga kami menemukan bahwa responden yang menonton televisi lebih dari dua jam secara tidak signifikan menyebabkan penurunan tajam penglihatan dibanding responden yang menonton televisi kurang dari dua jam ( $\mathrm{PR}=0,659$ [IK 95\%:0,221-1,962]). Beberapa studi juga menunjukkan bahwa aktifitas menonton televisi secara signifikan tidak berhubungan dengan penurunan tajam penglihatan. Hal ini disebabkan jarak seseorang menonton televisi bervariasi, sehingga tidak berhubungan signifikan. ${ }^{16}$ Di Desa Ngis sendiri jumlah penduduk yang memiliki televisi tidak banya, sehingga masyarakat menonton secara beramai-ramai dengan jarak pandang yang jauh.

Dalam penelitian ini kami mendapatkan bahwa responden yang menggunakan media elektronik dalam hal ini smartphone kurang dari 2 jam sehari mencapai 90,4\%. Akan tetapi, angka kejadian penurunan tajam penglihatan banyak terjadi yaitu mencapai $47,6 \%$. Responden yang menggunakan smartphone dan membaca buku lebih dari dua pada penelitian ini cenderung memiliki risiko lebih rendah mengalami penurunan tajam penglihatan dibanding dengan responden yang melakukannya kurang dari 2 jam. Studi pembanding menunjukkan bahwa melakukan aktivitas jarak dekat lebih dari 2 jam dapat memicu terjadinya penurunan tajam penglihatan. ${ }^{17}$ Studi lain di Norwegia juga menunjukkan bahwa aktivitas membaca buku memiliki hubungan positif dengan progresifitas penurunan tajam penglihatan. ${ }^{18}$ Perbedaan hasil yang ditemukan di Desa Ngis dengan studistudi sebelumnya dikarenakan Desa Ngis sendiri merupakan salah satu desa yang jauh dari daerah perkotaan, sehingga memiliki tingkat literasi dan ekonomi yang cukup rendah. ${ }^{12,19}$ Penduduk Desa Ngis yang memiliki smartphone dan juga televisi juga tidak banyak. Sehingga akses penduduk terhadap fasilitas tersebut sedikit jumlahnya.

\section{KETERBATASAN PENELITIAN}

Keterbatasan dalam penelitian ini adalah sebagian besar responden dalam peneltian ini berusia di atas 40 tahun. Sehingga responden memiliki risiko lebih tinggi mengalami gangguan penglihatan seperti age macular degeneration (AMD), katarak dan kelainan refraksi dan permukaan lainnya yang terkait dengan faktor usia. Sehingga dapat mempengaruhi pemeriksaan tajam penglihatan mata. Selain itu, jumlah responden yang sedikit dalam penelitian ini juga menjadi kendala yang menyebabkan rentang nilai kepercayaan menjadi lebar dan tidak signifikan. Desain penelitian potong lintang yang kami gunakan mempengaruhi hasil observasi faktor terkait dengan kejadian penurunan tajam penglihatan. Ditambah, screening yang dilakukan hanya satu kali pada tiap subjek yang berbeda dapat menimbulkan hasil yang berbeda di lain hari. Secara umum penurunan tajam penglihatan dipengaruhi aspek lingkungan dan juga aspek internal dalam hal ini adalah aktivitas luar ruangan dan jarak dekat atau dalam ruangan. Aktivitas dipercaya sebagai faktor terkait yang dapat menurunkan tajam penglihatan, sedangkan aktivitas luar ruangan dipercaya sebagai faktor protektif., ${ }^{9,10,13,15-18}$ Walaupun, secara nyata kami menemukan bahwa pada penduduk Desa Ngis aktivitas luar ruangan memiliki risiko lebih besar mengalami penurunan tajam penglihatan dibanding aktivitas dalam ruangan atau jarak dekat. Selain itu, keterbatasan pada aspek pemeriksaan kondisi dalam pusat visual di otak juga perlu diperhitungkan mengingat kemajuan teknologi neurovisual sedang gencar dilaksanakan dalam dasawarsa terakhir. ${ }^{20}$

\section{SIMPULAN}

Berdasarkan hasil penelitian dan pembahasan yang telah dilakukan dapat disimpulkan bahwa prevalensi kejadian penurunan tajam penglihatan masyarakat desa Ngis adalah 37 orang (48,7\%). Penurunan tajam penglihatan pada mata yang dialami oleh subjek bervariasi pada rentang nilai normal hingga NLP. Dengan faktor terkait aktivitas di luar ruangan dan bekerja di luar ruangan berkorelasi positif 
dengan tajam penglihatan, sedangkan faktor terkait menonton televisi, memakai smartphone dan membaca buku berkorelasi positif secara tidak signifikan.

\section{SARAN}

Terdapat berbagai faktor yang cenderung mempengaruhi penurunan tajam penglihatan antara lain kebiasaan menonton televisi, pemakaian smartphone dan aktivitas luar ruangan, masyarakat yang memiliki keluarga yang menggunakan kacamata, kebiasaan menggunakan televisi, dan kebiasaan membaca di dalam ruangan. Pengetahuan dalam pencegahan dan sikap masyarakat sudah tergolong cukup baik namun diperlukan upaya dalam pemeriksaan tajam penglihatan (screening) untuk mengetahui gambaran penurunan tajam penglihatan. Diperlukan juga upaya monitoring dan evaluasi dari puskesmas untuk memaksimalkan upaya pencegahan penurunan tajam penglihatan.

\section{UCAPAN TERIMA KASIH}

Peneliti mengucapkan terimakasih kepada $\mathrm{Ni}$ Made Ari Suryathi, Sp.M yang telah membimbing karya ilmiah ini hingga dapat di publikasi. Tidak lupa kami juga berterima kasih kepada I Made Marta Pradnyana selaku ketua panitia kegiatan Penelitian dan Pengabdian masyarakat (PENITI 2017) sebagai program kerja Himpunan Mahasiswa Kedokteran Umum (HMKU) FK Unud, serta seluruh teman panitia peniti yang membantu terlaksananya penelitian ini. Kami juga mengucapkan terima kasih kepada residen mata di RSUP Sanglah yang telah membantu dan membimbing peneliti dalam pemeriksaan tajam penglihatan dengan menggunakan Snellen chart.

\section{DAFTAR PUSTAKA}

1. Fricke TR, Tahhan N, Resnikoff S, Papas E, Burnett A, Ho SM, et al. Global Prevalence of Presbyopia and Vision Impairment from Uncorrected Presbyopia. Ophthalmology. 2018 Oct; 125(10): 1492-9. doi: 10.1016/j. ophtha.2018.04.013.

2. Bourne RRA, Flaxman SR, Braithwaite T, Cicinelli M V, Das A, Jonas JB, et al. Magnitude, temporal trends, and projections of the global prevalence of blindness and distance and near vision impairment: a systematic review and meta-analysis. Lancet Glob Heal. 2017 Sep 1;5(9):e888-97. doi: 10.1016/S2214-109X(17)30293-0.

3. Fricke TR, Holden BA, Wilson DA, Schlenther G, Naidoo KS, Resnikoff S, et al. Global cost of correcting vision impairment from uncorrected refractive error. Bull World Health Organ. 2012 Oct 1; 90(10): 728-38. doi: 10.2471/bly.12.104034.

4. Hashemi H, Fotouhi A, Yekta A, Pakzad R, Ostadimoghaddam H, Khabazkhoob M. Global and regional estimates of prevalence of refractive errors: Systematic review and meta-analysis. J Curr Ophthalmol. 2018 Mar; 30(1): 3-22. doi: 10.1016/j.joco.2017.08.009.
5. WHO. Universal eye health: a global action plan 20142019 [Internet]. Spain: WHO; 2013 [cited 2019 Jun 29]. 22 p. Available from: www.who.int/about/licensing/ copyright_form/en/index.html

6. Ziaei H, Katibeh M, Solaimanizad R, Hosseini S, Gilasi H-R, Golbafian F, et al. Prevalence of refractive errors; the yazd eye study. J Ophthalmic Vis Res. 2013 Jul; 8(3): 227-36.

7. Foster PJ, Jiang Y. Epidemiology of myopia. Eye [Internet]. 2014 Feb 10; 28(2): 202-8. doi: 10.1038/eye.2013.280.

8. Dolgin E. The myopia boom. Nature [Internet]. $2015 \mathrm{Mar}$ 18; 519(7543): 276-8.

9. Belete GT, Anbesse DH, Tsegaye AT, Hussen MS. Prevalence and associated factors of myopia among high school students in Gondar town, northwest Ethiopia, 2016. Clin Optom. 2017; 9: 11-8. doi: 10.2147/opto/s120485.

10. Goldschmidt E, Jacobsen N. Genetic and environmental effects on myopia development and progression. Eye (Lond). 2014 Feb;28(2): 126-33. doi: 10.1038/eye/2013.254.

11. Kementerian kesehatan Republik indonesia. Menkes luncurkan peta jalan Penanggulanan gangguan penglihatan [Internet]. 2017 [cited 2019 Jun 29]. Available from: http:// www.depkes.go.id/article/print/17101200004/menkesluncurkan-peta-jalan-penanggulangan-gangguanpengelihatan.html

12. Badan Pusat Statistik Kabupaten Karangasem. Kecamatan Manggis dalam Angka 2017 [Internet]. Karangasem; 2017 [cited 2019 Jun 29]. Available from: https:// karangasemkab.bps.go.id/publication/download. html? nrbvfeve $=$ NTVmOGY3NWFhNDg4MWY5Yz U5ODRjM2Qz\&xzmn=aHR0cHM6Ly9rYXJhbmdhc2 Vta2FiLmJwcy5nby5pZC9wdWJsaWNhdGlvbi8y MDE3LzA5LzIwLzU1ZjhmNzVhYTQ4ODFmOWM1OT g0YzNkMy9rZWNhbWF0YW4tbWFuZ2dpcy1kYWxhbS lhbmdrYSOyMD

13. Lin Z, Gao TY, Vasudevan B, Ciuffreda KJ, Liang YB, Jhanji V, et al. Near work, outdoor activity, and myopia in children in rural China: The Handan offspring myopia study. BMC Ophthalmol. 2017;17(1):1-8. doi: 10.1186/ s12886-017-0598-9.

14. Wang F, Gao Q, Hu L, Gao N, Ge T, Yu J, et al. Risk of Eye Damage from the Wavelength-Dependent Biologically Effective UVB Spectrum Irradiances. PLoS One. 2012;7(12):1-8. doiz: 10.1371/journal.pone.0052259.

15. Akinsola FB, Ajaiyeoba AI. Causes of low vision and blindness in children. West Afr J Med. 2002;21:1075-8.

16. Guan H, Yu NN, Wang H, Boswell M, Shi Y, Rozelle S, et al. Impact of various types of near work and time spent outdoors at different times of day on visual acuity and refractive error among Chinese school-going children. PLoS One. 2019;14(4). doi: 10.1371/journal.pone.0215827.

17. Lin Z, Vasudevan B, Mao GY, Ciuffreda KJ, Jhanji V, $\mathrm{Li} X X$, et al. The influence of near work on myopic refractive change in urban students in Beijing: a three-year follow-up report. Graefe's Arch Clin Exp Ophthalmol. 2016;254(11):2247-55. doi: 10.1007/s00417-016-3440-9.

18. Weissman B. the Influence of Near-Work on Development of Myopia Among University Students in Norway. Evidence-Based Eye Care. 2000;1(4):240-2. doi: 10.1097/00132578-200007000-00025.

19. Joewono M, Karmaya INM, Wirata G, Yuliana, Widianti IGA, Wardana ING. Drawing method can improve musculoskeletal anatomy comprehension in medical faculty student. Anatomy and Cell Biology. 2018;51(1):1418. DOI: https://doi.org/10.5115/acb.2018.51.1.14

20. Wirata, G., Karmaya, I.N.M., Muliarta, I.M. 2019. Longterm visual deprivation inhibit the visual lobe neocortex cytoarchitecture increment in 42 days male rats (Rattus norvegicus): a stereological study. IJBS 13(1): 48-52. DOI: 10.15562/ijbs.v13i1.183

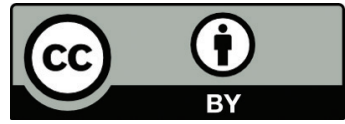

This work is licensed under a Creative Commons Attribution 